\title{
Ford Prefect or Volkswagen Golf? On the Differences in the Polish and Belarusian Translations of The Hitchhiker's Guide to the Galaxy
}

\begin{abstract}
This paper takes a relevance-theoretical approach to Douglas Adams' The Hitchhiker's Guide to the Galaxy in the Polish (Banaszak) and Belarusian (Kaściukievič) translation. The study treats translation as aiming for the optimal balance between the processing effort required of the reader, and the positive cognitive effect achieved, or, put differently, as fulfilling Gutt's communicability condition. In doing so, this paper indicates how vastly different outcomes are achieved depending on the translator's attitude and the choices one makes. The analysis includes a discussion of various elements of the novel, such as proper nouns, names of elements of the fantastic world, and cultural elements. The study reveals that Kaściukievič embedded his translation in the target culture more than the original was in the source culture, and thus achieved the communicability condition; on the other hand, Banaszak retained most of the cultural features of the original, which made her translation less relevant for the Polish reader.
\end{abstract}

Keywords: Belarusian language, Polish language, literary translation, Relevance Theory, The Hitchhiker's Guide to the Galaxy, proper nouns, elements of the fantastic world, cultural elements

\section{Introduction}

Translation is not concerned only with the language and conveyance of word or sentence meaning; it is a complex process inevitably bonded with culture - language is embedded in culture and 
culture shaped by language - thus, the two are inseparable. Choosing one or another way of expressing a thought can generate contrasting effects, and the analysis of the translator's choices, as well as its consequences, has long lied in the heart of translation studies. One of the most prominent theories juxtaposes foreignization with domestication. As Venuti asserts, "Foreignizing translation in English can be a form of resistance against ethnocentrism and racism, cultural narcissism and imperialism, in the interests of democratic geopolitical relations" (20). This rule interpreted inversely, i.e., domesticating a translation from English, especially into a minority language, expresses resistance against all the negative forces of lingua franca. Such opposition between two contrasting types of translation is also described in terms of Nida's dynamic and functional equivalence in translation (1964).

These theories treat translation in a binary way and are more focused on the text and the translator than on the recipient. For this reason, the paper addresses the intricate relationship between translation and culture using the Relevance Theory (henceforth RT). In doing so, it treats the text as a form of communication, focusing on the audience's reaction to the particular elements of the text. Scrutinizing the details of the Polish and Belarusian translations (by Anna Banaszak and Pavał Kaściukievič respectively) of The Hitchhiker's Guide to the Galaxy by Douglas Adams, this analysis enables an attempt at grading the translations according to the level of the balance between the processing effort required of the reader and the positive cognitive effect achieved.

\section{Relevance Theory - Basic Concepts and Application in the Translation Studies}

RT was first introduced in the mid-80s by Deirdre Wilson and Dan Sperber, and it has since evolved significantly due to both the further improvements made by its authors (2004) and the developments introduced by a growing number of scholars. The theory is rooted in Grice's claim that an ability to express and recognize intentions is crucial for human communication (59). The intended interpretation of the utterance consists of explicatures - the exact words communicated, and implicatures - the contextual assumptions the Speaker wants to communicate, i.e., the information conveyed implicitly. In RT, context is a psychological rather than physical construct; it refers to the cognitive environment of the Speaker and the Hearer, to their assumptions about the 
world. The key factor in RT is that the context is not ready and waiting to be used for the interpretation of an utterance. The Hearer chooses the context in search for the relevance.

As Wilson \& Sperber assert, humans seek optimal relevance in communication, in other words, they communicate in a way that allows recognizing the intended message and does not require the Hearer to make a redundant effort (612). This means that the first interpretation the Hearer arrives at is presumed to correspond to what the Speaker intended to communicate, what the Speaker meant. RT claims there can always be only one such interpretation. Yet, there is no guarantee that the first interpretation the Hearer arrived at is always the one intended by the Speaker - it is a wellknown fact that misunderstandings occur in real-life situations.

RT has been applied in many linguistics fields, including translation studies. Such an application of RT was put forward by ErnstAugust Gutt (2000) in his work "Translation and Relevance," which gives a brief overview of the main RT concepts as well as their implications for translations studies. Gutt drew from Wilson \& Sperber's requirement of adequate cognitive effects without unnecessary processing effort, the notion of communicability condition: "A body of thought can be communicated to an audience only to the extent that the necessary contextual information is readily accessible in their cognitive environment" (322). Whatever the solution chosen by the translator, it should fulfil the communicability condition.

The audience, while reading the translation, arrives at a first relevant interpretation based on the assumptions available in their cognitive environment. This process is automatic and, therefore, the translator should make an attempt at identifying the elements of readers' cognitive environment in order to convey the message in a way that minimizes the processing effort and maximizes the positive cognitive effect. The more distinct the differences between these environments are, the more difficult the task of the translator. As we shall see in the following pages, The Hitchhiker's Guide is among the most challenging, partly due to the context in which it was created.

\section{The Hitchhiker's Guide to the Galaxy and Its Translations}

In the late 1970s, Douglas Adams started the BBC Radio 4 series called The Hitchhiker's Guide to the Galaxy. It received a great response from the audience and was soon published as a book, the 
first of the several more to come. The adventures of an Earthman and his alien friend in the Galaxy have since been a constant inspiration for creators of TV series, films, stage shows, comic books, music, and video games. The gist of The Hitchhiker's Guide popularity, lasting even 40 years after it was first published, is its humor. On the one hand, it is deeply embedded in the English culture and the sense of Englishness, but on the other, the situational humor and the use of satire to mock some of the culturally universal human flaws are well understood among all types of readers (Zohra).

Therefore, unsurprisingly, The Hitchhiker's Guide has been translated into more than thirty languages, including Polish and Belarusian. To date, there are two Polish translations - one by Anna Banaszak (1986) and one by Paweł Wieczorek (1994); and only one Belarusian by Pavał Kaściukievič (2015). Wieczorek has a much richer experience in translating the British and American literature (OCLC Online Computer Library Center, "Wieczorek, Paweł.") than Banaszak, who has, according to the WorldCat Identities, translated only two books so far (OCLC Online Computer Library Center, "Banaszak, Anna”). However, the earlier Banaszak's translation was chosen for this analysis, since it was the first attempt at translating The Hitchhiker's Guide into Polish, and it is not significantly different from Wieczorek's translation; additionally, it serves as a good contrast to the Belarusian translation by Kaściukievič. Neither of the two Polish translations has been extensively analyzed, only a certain part, namely, the Vogon's poetry, discussed by Agnieszka Majcher (2015). Polish renditions have not been widely commented among readers' community either. A handful of reviews (Bębenek; Iga) positively assess Wieczorek's work; however, other than that, there is no information about how the translations were received by the Polish audience. On the other hand, the publicity around the Belarusian translation was much different, not merely because it was the first in this language, but due to its quality. Kaściukievič's version of The Hitchhiker's Guide was shortlisted for two major translation awards - Janka Maŭr Literary Award "Exlibris" (Press Office of the Union of Belarusian Writers), and Karl Sherman Award (Novy Čas editors), both cofunded by the Belarusian PEN Centre and considered prestigious awards among the Belarusian translators. Apart from the professional community, the Belarusian audience also esteemed Kaściukievič's translation very highly. The book launch attracted much attention of the Adams' loyal fans, and the translation has been described as very 
daring, owing to the fact that the texts include a lot of direct references to the Belarusian culture (Dorskaja). Reviewers stress the originality of Kaściukievič's text and recommend it even to readers well familiar with the English original, or other translations, such as Russian editions of the English texts popular in Belarus (Kurhanava).

The difference in the publicity around the Polish and Belarusian translation of The Hitchhiker's Guide might simply indicate how the two publishing markets vary - the Polish one is highly saturated and the publishing houses usually focus on the latest best-sellers rather than on the new editions of classics, while the Belarusian-language publications of renowned literary works are much rarer and therefore attract more attention. As we shall see in the following part of this paper, there is yet another possible explanation of the differences in the reception of the Polish and Belarusian text, one that is closely connected with the translator's attitude and applied solutions, as observed through the RT framework.

\section{Polish and Belarusian Translations - Differences in Approaching the Challenge of Translating Culturally- and Linguistically-Embedded References}

The elements of the novel that pose a significant challenge for a translator are numerous and therefore they have been divided into three main groups based on their function, that is, the proper nouns, the elements of the fantastic world described with neologisms, and the elements of the or the references to (not only source) culture. The differences between solutions chosen by the Polish and Belarusian translator are considered from the point of view of the reader and the amount of processing effort as compared to achieved positive cognitive effects.

\subsection{Proper Nouns}

The Hitchhiker's Guide is full of proper nouns invented by Adams, as well as those functioning in the real world, though in a very different context. Most of the proper nouns are intended to have a comic effect on the reader by subtle cultural associations, or by playing with the word form. A number of examples is discussed in the following paragraphs. 
Ford Prefect (Eng.) - Ford Prefect (Pol.) - Фольксваген Гольф [Folksvahien Holf] (Bel.)

Ford Prefect, a friend of the main character, is, as we find out at the very beginning of the story, an alien from the planet called Betelgeuse V. Since he came to the Earth to gather information about our planet, he needed a cover story:

The information he had gathered had led him to choose the name "Ford Prefect" as being nicely inconspicuous. (Adams 8)

This sentence has been translated into the Polish language in the following manner:

uznał że nazwisko „Ford Prefect” będzie wystarczająco pospolite i nie będzie się zbytnio rzucało w oczy! ${ }^{[1]}$ (Banaszak 9)

Ford Prefect is a line of British cars which was produced between 1938 and 1961, but it was still very popular in the United Kingdom when The Hitchhiker's Guide was created. In Poland, that particular model is not very well known; however, the brand itself is easily recognizable, and with little effort, the reader can guess that the choice of the name was a mistake. In Belarus, on the other hand, Fords are rare - so the translator decided to render the above-mentioned fragment as follows:

Інфрармацыя, што прыхапкам назапасіў Артуравы сябар, прывяла яго да выбару імені і прозвішча Фольксваген Гольф: ён зрабіў выснову, што такое спалучэнне было вельмі пашыраным на Зямлі, а таму гучала звыкла і някідка. ${ }^{[2]}$ (Kaściukievič 14)

Volkswagen Golf is a car model that has been produced since 1974 and is one of the most popular in Belarus; in fact, it is also the third most popular model in Poland (Grabowski). Had the Belarusian translator used the name Ford Prefect, the target audience would not infer the right assumption from their cognitive environments and the comic effect would not be transferred. Slartibartfast (Eng.) - Slartibartfost (Pol.) - Пердылюбібляйц [Pierdylubiblajc] (Bel.) 
Slartibartfast, a planet designer, is not very eager to reveal his name in a conversation with the main character of the story:

"My name?" said the old man, and the same distant sadness came into his face again. He paused. "My name," he said, "... is Slartibartfast." (Adams 104)

The Polish translator uses the same name with a slight change in the last syllable - a change that cannot be attributed to any aim, as it does not cause the Polish reader to draw any assumptions from their cognitive environment:

— Jak się nazywam? — powtórzył człowiek i ten sam odległy smutek znów pojawił się na jego twarzy. Milczał przez chwilę. - Nazywam się - powiedział - Slartibartfost. ${ }^{[3]}$ (Banaszak 105)

As Adams admitted in his notes on the original scripts of the radio series, he wanted this name to sound vulgar, yet acceptable enough to be broadcast. He achieved his goal by combining the word 'fast' with a syllable sequence that recalls the word 'fart'. Indeed, Urban Dictionary, however controversial and unprofessional (Chang), defines 'slart' as "a slimy or slippery fart" (Urban Dictionary). In the Polish language, such a composition of sounds does not remind the reader of anything, and therefore the comic effect is completely lost. The Belarusian translator, on the other hand, tried to convey Adams' original assumptions concerning the name:

- Маё? - перапытаў дзядок, і зноўку тая самая замаркочанасць пракінулася ў ягоных вачах. Дзядок зрабіў паўзу. - Маё імя, - зноў загаварыў ён, - Пердылюбібляйц:[4]

(Kaściukievič 158)

‘Пердылюбібляйц’ [Pierdylubiblajc] consists of three morphemes: ‘Перды’ which means 'farts' and 'любі-бляйц' in which the latter indicates a subject of a verb and the former derives from the verb 'любіць' - 'to like' or 'to love'. Surprisingly, this variant also sounds funny to the Polish language speakers as the first and the second morpheme sound and mean the same in Polish.

Pan Galactic Gargle Blaster (Eng.) - Pangalaktyczny Dynamit Pitny (Pol.) - Пангалактычны Мазгатрушч [Panhałaktyčny mazhatrušč] (Bel.) 
This alcoholic drink is believed to be the best in the universe, and this is what 'pan' refers to according to the Cambridge dictionary, it means "including or relating to all the places or people in a particular group" ("Pan-"). 'Gargle' means to "wash one's mouth and throat with a liquid that is kept in motion by breathing through it with a gurgling sound" ("Gargle"). The use of the word 'blaster', which derives from 'blast': "to explode or destroy something or someone with explosives, or to break through or hit something with a similar, very strong force," ("Blast") corresponds with the alcohol's effect which is like having your brains smashed out by a slice of lemon wrapped round a large gold brick.

The Polish translation of the name repeats the first and the second part in reference to 'Gargle Blaster'. 'Dynamit' means 'dynamite', which is strongly associated with 'blast', whereas 'pitny' means 'drinkable' - hence the name evokes a picture similar to the one in the original and, in effect, helps the reader minimize the processing effort necessary for understanding the name.

The Belarusian translator, on the other hand, chose a name that strongly relates to the effect cited in the point (a). 'Пангалактычны' [panhałaktyčny] has exactly the same meaning as in the case of the English and Polish version, but 'Мазгатрушч' [mazhatrušč] derives from two words 'мазгі' 'brain', and 'трасці' - 'shake', underlining the effect of the alcohol in question and therefore allowing for achieving very similar cognitive effect to the one achieved by the English and Polish audiences.

Apart from these humorous examples, there is a number of proper nouns not evoking any particular association in English readers but are translated into Belarusian in such a manner that makes the fantastic world seem familiar to the target audience.

Qualactin (en.) - Qualactina (Pol.) - Паляшус (Bel.) [Palašus]

The name of this planet is mentioned in the recipe for the "Pan Galactic Gargle Blaster." The Polish translation does not differ from the source language term; however, the Belarusian refers to a region of Belarus called Palessie. The Belarusian translator might have chosen this specific region since Palessie is commonly associated with folk mythology and supernatural events, and the original text describes the planet as 'dark' and 'mystic', therefore the choice in the Belarusian translation helps the reader draw assumptions compatible with the planet's features. 
land of Poghril (en.) - kraj Poghrilów (Pol.) - планета Янкагрыль (Bel.) [Jankahrył]

The land of Poghril, whose inhabitants died of starvation, is mentioned in the scene when the main characters hitch a spaceship. The Polish translator does not alter this name; the Belarusian, however, uses a reference to a well-known Belarusian writer, Janka Bryl, and the reason might be twofold. Firstly, the twisted surname (Bryl-Hrył) sounds similar to the original 'Poghril', and secondly, Janka Bryl is most widely recognized as the co-author of the novel Out of the Fire, a terrifying story of a village burnt down together with its inhabitants by the Nazi soldiers, and therefore deserted - just like Adams' Land of Poghril. Kaściukievič's procedure minimises the effort needed for processing the name and yields positive cognitive effects stronger than the original in case of the source audience.

Oolon Coluphid (en.) - Oolon Coluphid (Pol.) - Валенштайн-Акудовіц (Bel.) [Valenštajn-Akudovic] The name of a philosopher, author of a famous trilogy, was translated into the Belarusian language using a distorted version of the name 'Valancin Akudovič', who is a Belarusian philosopher and poet. Due to its obvious connotations, it is easier for Belarusian readers to draw the right assumptions from their cognitive environments and instantly associate the character with philosophy than it might be in the case of the source audience and Oolon Coluphid.

Brantisvogan bank (Eng.) - bank brantisvogoński (Pol.) - 3'ешНеЭканомьБанк (Bel.) [ZješNieEkanomBank]

Brantisvogan bank is a place where one of the characters kept money of suspicious origin. While Banaszak named the institution in the same manner as Adams, Kaściukievič invented a name that literally means '(you will) eat-no-econom-bank'. It is not only the reference to the unfair practices of Brantisvogons but also to one of the Russian-owned banks of a questionable reputation and a strikingly similar name, 'Vnešeconombank'.

Reader's Digest (Eng.) - Reader's Digest (Pol.) - Наша піва (Bel.) [Naša piva]

After one of the main characters expresses a philosophical thought, his friend ironically proposes he should send it to Reader's Digest. Reader's Digest, a magazine founded in the United States almost a century ago, now with international editions in over 70 countries, is known to be unsophisticated, presenting easily accessible art targeted at people who deploy the arts to gain 
social prestige (Smith). The Polish translator used the name 'Reader's Digest' since it is the title of the Polish version of the magazine. Nevertheless, it does not convey any traits associated with it in the Anglophone culture and, therefore, does not yield the same cognitive effects as it does in the case of the source audience.

The Belarusian translator decided to use a name that, on the one hand, literally means 'our beer', and on the other hand is a distorted version of the title 'Naša Niva' - one of the oldest Belarusian newspapers, which played an important role in the development of the Belarusian literature and has become a cultural symbol. Due to this strategy, the effect of irony seems strengthened, and, additionally, the comic effect achieved.

Soulianis and Rahm (Eng.) - Soulianis i Rahm (Pol.) - Ярыла і Яморда (Bel.) [Jaryła i Jamorda] These are the names of twin suns around which the planet Magrathea orbits. While the Polish translation contains the same proper nouns, the Belarusian versions are built upon a wordplay and cause comic effect, since 'Ja-ryła' and 'Ja-morda' mean essentially the same. 'Morda' is the Belarusian equivalent of a 'muzzle' but it can also mean 'a person's face' in a pejorative context, and 'ryła' (Ozhegov and Shvedova) is Russian variant of 'morda'. The Belarusian translation certainly minimizes the cognitive effort needed for processing the name and triggers a much stronger reaction from the target audience than it does in the case of source or Polish readers.

Ciceronicus 12 (Eng.) - Ciceronicus dwanaście (Pol.) - Альбарутэнікус-94 (Bel.) [Albaruteniks] Ciceronicus 12 is a planet from which originates one of the most powerful computers. The name most probably refers to the Roman philosopher and orator Cicero. While Cicero is well-known in both Polish and Belarusian culture, Kaściukievič decided to use another reference, one strictly connected with the Belarusian history - 'Ruthenia Alba', which is Latin for 'Belarus', making it sound more familiar and yielding a more powerful cognitive effect on the target audience.

\subsection{Elements of the Fantastic World}

SubEtha Sens-O-Matic (Eng.) - sub-etha sens-o-manc (Pol.) - Субэфірны адчувальнік (Bel.) [Subefirny adčuvalnik] 
It is a device that can register the appearance of a passing-by spaceship. SubEtha is the name of the technology, namely a telecommunication network for hitchhikers - the name derives from a noun 'ether', meaning "clear sky," or, informally, "air regarded as a medium for radio" ("Ether"). The name of the device is constructed from the verb 'to sense' and a suffix 'o-matic', frequently appended in the 1950s and 1960s to the names of machines to indicate their primary function (Booij et al. 968).

The Polish translator has slightly changed the last part of the name using 'manc', instead of 'matic', however, it does not make the Polish reader infer additional associations easier. The Belarusian translator used the full word 'subefirny', easily understood as 'under-the-ether' (where 'ether' has the same meaning in the Belarusian and English language), and the noun 'adčuvalnik', which derives from the verb 'adčuvać' - 'to sense'. Therefore, the reader can infer it is a device that can sense what is happening in the air, in the sky; and the effort necessary for processing this neologism remains at a minimal level.

SubEtha News-Matics (Eng.) - Sub-etha news-matiki (Pol.) - Субэфрірныя навіннікі (Bel.) [Subefirnyja navinniki]

The pattern of translating the first part of this name, 'SubEtha', is the same as in the abovementioned examples, the difference in this particular case lies in the second part, that is 'NewsMatics'. The Belarusian translation is constructed from two elements: 'navin', from the word 'naviny' (meaning news), and the suffix 'iki', used to form nouns denoting subjects of an action, or an item having a particular function. The original name generates assumptions of a machine producing news, and so does the Belarusian version. In the case of the Polish translation, 'news', due to internationalization processes, is quite easily recognizable, however, the part 'matiki', might be questionable. It is a Polonised version of the suffix 'matics' - ' $c$ ' is turned into ' $k$ ' according to the pronunciation, and the plural noun suffix ' $i$ ' is added in place of English 's'. The overall effect is rather humorous since the resulting suffix 'ki' is commonly used in the Polish language to form diminutives, therefore, the positive cognitive effect, although achieved at a rather low cost, is not as close to the original as it is in the case of the Belarusian translation.

Nutri-Matic machine (Eng.) - Maszyna nutri-matyczna (Pol.) - Стравамат (Bel.) [Stravamat] 
In this example, 'nutri' derives from 'nutrition', which does not function in the Polish language, let alone in vocabulary connected with nutrition. The only part which allows inferring any associations is the straightforward 'maszyna', literally meaning 'machine', and the suffix 'matyczna', which is a part of the adjective 'autmatyczna' ('automatic', female). 'Stravamat', on the other hand, comes from the word 'straŭnik', meaning 'stomach', therefore making it easier for the Belarusian readers to draw the right assumptions from their cognitive environment.

Kill-O-Zap gun (Eng.) - karabin kill-o-zap (Pol.) - смерцямёт (Bel.) [śmierciamiot]

The name consists of two main elements, the conjunction of verbs 'to kill', neutral in meaning, and 'to zap', which is much stronger and means to destroy, or eradicate in a comic, satirical sense (“Zap"). In the Polish translation, 'gun' is rendered as 'karabin', literally meaning 'carabin', which is a type of gun. 'Kill' is recognizable to Polish language users, mainly from the context of the popular culture, but the sense that 'zap' conveys is lost, as the target audience cannot infer any meaning from it. The Belarusian translation consists of two parts - 'śmierć', which means 'death', and 'miot' from the word 'miotać', which means 'to throw' or 'to launch'. The final version of the name means 'a device that throws death', and even though the processing of this translation requires minimum effort on the part of the reader, it does not render the comic effect 'zap' does.

Damogran Frond Crested Eagle (Eng.) - Damograński liściasty orzeł grzebieniasty (Pol.) Чубковая папараць-птушка (Bel.) [Čubkovaja paparać-ptuška]

The name describes a non-existent bird, translated into the Polish language quite literally. 'Frond', which is "a long, thin leaf of a plant" ("Frond"), was rendered with the adjective 'liściasty'. It comes from 'liść' which means 'leaf'. 'Grzebieniasty' literally means 'crested'. This part was also translated literally into the Belarusian language - ‘čubkovaja'. The reference to the plant, on the other hand, was used to invoke an important Belarusian cultural element. 'Paparaćptuška', literally 'fern-bird', indicates it is not a real animal, similarly to 'paparaćkvietka', a mythical flower of fern in the Belarusian folk culture, believed to blossom only once a year during the Kupała Night (Kryuchkova and Kryuchkova).

towel (Eng.) - ręcznik (Pol.) - ручнік (Bel.) [ručnik] 
Translating a word as common as 'towel' does not leave much space for doubt. However, in this case, the Belarusian reader has additional associations since 'ručnik' is an important item used in many rituals and religious ceremonies; each specimen decorated with multiple symbols, depending on the occasion or the region. Adams makes the towel part of the hitchhikers' culture and mentions

"a phrase which has passed into hitchhiking slang, as in Hey, you sass that hoopy Ford Prefect? There's a frood who really knows where his towel is." (Adams 18)

Since 'towel' is firmly embedded in the Belarusian culture, Kaściukievič uses it as an opportunity for conveying the association with the target culture and renders the fragment:

“Ручнік стала ўвайшоў у народную творчасць. Вось, да прыкладу, словы са старажытнай песні аўтаспыннікаў: «У касмапорт ты мяне на зары праваджала і ручнік вышываны мне на шчасце, на волю дала». ${ }^{[5]}$ (Kaściukievič 30)

It is not only a reference to the Belarusian but also to Slavic culture, as this "ancient song of hitchhikers" is actually a paraphrase of the Ukrainian folk song "Ridna mati moja" (TUT.BY Editors). In Polish culture, 'ručnik' does not evoke any associations similar to these found in the Belarusian culture; therefore, no additional cognitive effect is achieved.

\subsection{Cultural Elements}

Units of measurement

Imperial units, such as miles, feet, and inches, are left unchanged by Banaszak, even though they are unknown in the Polish culture, and a typical Polish reader does not know if a mile is closer to the decimeter or kilometer. In the Belarusian translation, on the other hand, the decimal units are used and value recalculated; e.g. six feet is translated as two meters. It is an approximation since six feet is exactly 1.82 meters; however, it minimizes the cognitive effort necessary for processing the information.

Song 
In a moment of fear, the spaceship computer Eddie is singing a song, You'll Never Walk Alone. It comes from the 1945 musical Carousel but is broadly known as Liverpool F.C. football fans' anthem, and it thus has strong cultural connotations. Banaszak translated the lyrics literally, while Kaściukievič chose to use a paraphrase of a children's song from Soviet times. This strategy, in turn, caused the effect of inappropriateness, very similar to the original, and at the same time minimised the processing effort by using easily accessible cultural associations.

\section{Swear words}

Characters of The Hitichhiker's Guide - one of them in particular - use swear words on multiple occasions. Zaphod utters phrases of various intensity to express his emotions: 'hell', 'what the hell', 'what the photon', 'who the devil', 'shit', etc. These were translated into the Polish language using a range of variants, 'cholera' and 'u diabła', among others. In the Belarusian translation, however, a single phrase was used - 'халера-венера' [chalera-vieniera]. 'Chalera' is the closest equivalent of 'shit', and 'venera' literally means 'Venus', additionally, it rhymes with 'chalera' and creates a comic effect.

Character's achievements in contests

Interesting items appear in the description of one of the characters, Beeblebrox, who is quite famous in the galaxy. He's been referred to as:

the Best Bang since the Big One, and recently voted the Worst Dressed Sentient Being in the Known Universe. (Adams 65)

This fragment has been translated by Banaszak in the following manner:

określony ... mianem najlepszej sprężyny od czasu Wielkiego Wybuchu, wybrany ostatnio ... Najgorzej Ubraną Rozumną Formą Życia w znanym wszechświecie. ${ }^{[6]}$ (Banaszak 66)

The humor of the first descriptor, playing with the sexual and astrophysical context, is altogether lost in the Polish translation, and since the name of the contest is translated quite literally, it has no 
positive cognitive effect on the target reader. Kaściukievič, on the other hand, chose to name Beeblebrox:

«сэкс-тытанікам» бо яго полавая моц саступае адно Саюэ-Апалону Бельведзерскаму. Біблброкс, які перамагаў у «Еўрасабачанні, (']] (Kaściukievič 102)

In this case, the sexual context is underlined by a comment added to the "title," apart from that, it also has a wordplay, although with a more familiar name, 'Titanic', commonly associated with considerable size and power. Further, the name of the contest won by Beeblebrox is a twisted version of the name 'Eurovision'. The Belarusian analogue is 'Еўрабачанне' [Jeŭrabačannie], and adding the syllable 'sa' makes it sound humorous to the Belarusian reader since the product of this procedure is a noun derived from the adjective 'sabačy', meaning 'dog-like', usually used in a negative context.

\section{Conclusions}

Relevance Theory treats the reader as a psychological entity, and it proposes that the target audience's ability to access the author-intended context is a crucial factor in translation. RT gives an insight into the process of reception of the translation and suggests certain ways of optimizing it. In the case of The Hitchhiker's Guide to the Galaxy, one can observe various means of maintaining the balance between the amount of cognitive effort (the effort necessary for understanding the authorintended communicate) and the quality of the cognitive effect (the degree to which the communicate is understood as intended). This, however, concerns mainly the Belarusian translation. Kaściukievič, the translator, applies various procedures for conveying the message and enabling the reader to arrive at the author-intended contextual assumptions.

Firstly, the names of the characters and devices from the fantasy world created by Adams in many cases carry additional meaning - explaining the application of an item (as in 'SubEtha SensOMatic'), underlining some features of a character (like the name 'Ford Prefect', demonstrating its owner's lack of knowledge about the planet Earth and its inhabitants), or simply creating a comic effect (as the name 'Slartibartfast'). 
In the Polish translation the proper nouns are usually used in the same form as in the original; they are not translated (with just few exceptions). The Belarusian translator, on the other hand, makes an attempt at finding elements of the Belarusian language and culture that could evoke similar emotions and associations in Belarusian readers as the original evokes in the source audience. Additionally, the Belarusian translator adds references to the target culture in passages that do not have any additional (explicit or implicit) meaning for the original reader. Therefore, he makes the translation more embedded in the Belarusian culture and makes the novel's world (originally, even though explicitly fantastic, still perceptibly British) seem more familiar to the target audience.

The Belarusian translation of The Hitchhiker's Guide, it can be concluded, is more in accordance with Gutt's communicability condition than its Polish counterpart; as in most cases, the cognitive effort necessary for processing the text is successfully minimized and the positive cognitive effect maximized. Kaściukievič is "domesticating," as Venuti would have it, or using "dynamic equivalence," as Nida would describe it, and is consequently intervening, rewriting the story in order to create a Belarusian artefact, not just a translation of a foreign artefact.

\section{Works Cited}

Adams, Douglas. The Hitchhiker's Guide to the Galaxy. Pan Books, 1979.

Adams, Douglas. Autostopem przez galaktykę. Translated by Anna Banaszak, Faktor, 1992.

Adams, Douglas. Aŭtaspynam pa hałaktycy. Translated by Pavał Kaściukievič, Łohvinaŭ, 2015.

Bębenek, Michał. "Nie panikuj - Douglas Adams - "Autostopem przez Galaktykę."' Głos Kultury, 17 Oct. 2016, www.gloskultury.pl/nie-panikuj-douglas-adams-autostopem-przez-galaktyke-recenzja/. Accessed 1 June 2020.

"Blast." Cambridge English Dictionary, 2019, dictionary.cambridge.org/dictionary/english/blast. Accessed 1 June 2020.

Booij, Geert E., et al. Morphologie / Morphology. 1. Halbband. Walter de Gruyter, 2000.

Chang, Clio. "Why Urban Dictionary Is Horrifically Racist." The New Republic, July 2017, newrepublic.com/article/143704/urban-dictionary-horrifically-racist. Accessed 1 June 2020. 
Dorskaja, Alaksandra. "«Spakucha!»: «Aŭtaspynam pa hałaktycy» prezientavali pa-biełarusku." ["Don't panic!": "The Hitchhiker's Guide to the Galaxy” presented in Belarusian] Naša Niva, 23 Apr. 2015, nn.by/?c=ar\&i=148225. Accessed 1 June 2020.

“Ether." Lexico Dictionaries, 2019, www.lexico.com/en/definition/ether.

"Frond." Cambridge English Dictionary, 2019, dictionary.cambridge.org/dictionary/english/frond.

"Gargle." Lexico Dictionaries, 2019, www.lexico.com/en/definition/gargle.

Grabowski, Tymon. "50 najpopularniejszych używanych aut w Polsce." [50 most used cars in Poland] Autoblog.pl, 9 Mar. 2018, spidersweb.pl/autoblog/50-najpopularniejszych-uzywanych-autw-polsce/. Accessed 1 June 2020.

Grice, H. P. "Logic and Conversation." Syntax and Semantics, Volume 3: Speech Acts, edited by J.L. Morgan and P. Cole, vol. 3, 1975, pp. 41-58.

Gutt, Ernst-August. "Relevance and Translation: On the Value of a Good Theoretical Foundation of Translation." In the Mind and Across Minds: A Relevance-Theoretical Perspective on Communication and Translation, edited by Ewa Wałaszewska et al., Cambridge Scholars Publishing, 2010, pp. 292-310.

Gutt, Ernst-August. Translation and Relevance. 2nd ed., St. Jerome Publishing, 2000.

Iga. "Douglas Adams - Autostopem Przez Galaktykę." [Douglas Adams - The Hitchhiker's Guide to the Galaxy] Książkowir, 13 Sept. 2016, naszksiazkowir.blogspot.com/2016/09/douglas-adamsautostopem-przez-galaktyke_13.html. Accessed 1 June 2020.

Kryuchkova, Olga, and Elena Kryuchkova. Illustrated Encyclopedia of Ancient Slavic Gods and Spirits. Translated by Inna Rutkovska, Babelcube Inc., 2019.

Kurhanava, Śviatłana. "Byccio — marnaje. Nu i što?" [Existence is miserable. So what?] zviazda.by, 3 Sept. 2018, zviazda.by/be/news/20180903/1535976581-byccyo-marnae-nu-i-shto. Accessed 1 June 2020.

Majcher, Agnieszka Elżbieta. “Jak tłumaczyć poezję Vogonów z powieści „Autostopem przez galaktykę" Douglasa Adamsa? Konteksty, inspiracje, korespondencje." [How to translate poetry 
from the novel "The Hitchhiker's Guide to the Galaxy" by Douglas Adams? Contexts, inspirations, correspondences] Studia Filologiczne UJK, vol. 28, no. 2, 2015, pp. 127-38.

Nida, Eugene Albert. Toward a Science of Translating: With Special Reference to Principles and Procedures Involved in Bible Translating. E.J. Brill, 1964.

Novy Čas editors. "Abvieščany šort-list premii imia Karłasa Šermana." [Short-list of the Carlos Sherman Award announced] Новы Час, 14 Oct. 2016, novychas.by/kultura/abveszczany-szort-listpremii-imja-karlasa-szerman. Accessed 1 June 2020.

OCLC Online Computer Library Center. "Banaszak, Anna." WorldCat Identities, 2019, worldcat.org/identities/viaf-165970567/. Accessed 1 June 2020.

OCLC Online Computer Library Center. "Wieczorek, Paweł." WorldCat Identities, 2019, worldcat.org/identities/viaf-101788149/. Accessed 1 June 2020.

Ozhegov, S. I., and N. Shvedova. "Rylo." Tolkovyı̆ Slovar' Ozhegova Onlaĭn [Online Dictionary of Spoken Language by Ozhegov], 1992, pp. 944, slovarozhegova.ru/word.php?wordid=27522. Accessed 1 June 2020.

"Pan-." Cambridge English Dictionary, 2019, dictionary.cambridge.org/dictionary/english/pan.

Press Office of the Union of Belarusian Writers. "Vyznačany pieramožcy konkursu "Ekslibrys" imia Janki Maŭra' [The winners of the Janka Maŭr contest "Exlibris" announced]. Sajuz Biełaruskich Piśmiennikaŭ, 9 Nov. 2013, lit-bel.org/news/Viznachani-peramozhtsi-konkursu-ekslbris-mya-YankMara-4175/. Accessed 1 June 2020.

Smith, Alexander McCall. "Reader's Digest: A Teacher, and a Friend.” The Telegraph, 19 Feb. 2010, www.telegraph.co.uk/finance/newsbysector/mediatechnologyandtelecoms/7265161/ReadersDigest-a-teacher-and-a-friend.html. Accessed 1 June 2020.

TUT.BY Editors. 'U Minsku prezientujuć biełaruskuju viersiju ramana Duhłasa Adamsa "Aŭtaspynam pa hałaktycy." [The Belarusian Version of Douglas Adams' Novel "The Hitchhiker's Guide to the Galaxy" Has Been Presented in Minsk] TUT.BY, 22 Apr. 2015, news.tut.by/society/445021.html. Accessed 1 June 2020. 
Urban Dictionary. 'Slart'. Urban Dictionary, www.urbandictionary.com/define.php?term=Slart.

Accessed 3 Oct. 2019.

Wilson, Deirdre, and Dan Sperber. "Relevance Theory." The Handbook of Pragmatics, edited by

Laurence Horn and Gregory Ward, Blackwell, 2004, pp. 607-32, www.dan.sperber.fr/?p=93.

Accessed 1 June 2020.

"Zap." Cambridge English Dictionary, 2019, dictionary.cambridge.org/dictionary/english/zap.

Accessed 1 June 2020

Zohra, Fatima. "Humor, Satire and Verbal Parody in The Hitchhiker's Guide to the Galaxy: A

Relevance Theoretic Approach." NUML Journal of Critical Inquiry, vol. 14, no. 2, 2016, pp. 38-53. 
[1]He decided that the name „Ford Prefect” would be common enough and would not stick out too much (all back translations by the author of this paper).

[2]The information Arthur's friend had gathered in a rush led him to the choice of the name and surname Volkswagen Golf: he concluded the phrase was very popular on the Earth, and therefore sounded common and discreet.

[3]- What is my name? - repeated the man and the same distant sorrow appeared again on his face. He was silent for a moment. - My name is, - he said - Slartibartfost.

[4]- My? - asked again the man and again the same sorrow appeared in his eyes. The man made a pause. - My name is, - he said again, - Pierdylubiblajc.

[5]'Ručnik' entered the folk art for good. So, for example, here are the words of ancient hitchhikers' song: "In the spaceport you lead me on the star and embroidered ručnik you gave me for luck, for freedom" (back translation mine).

[6]Described ... as the best spring since the Big Bang times, recently chosen ... the Worst Dressed Sentient Being in the known universe.

[7]"Sex-titanic," because his sexual power gives way only to Sajue-Apałon Bielviedzierski. Beeblbrox who won in „Jeŭrasabačannie.”

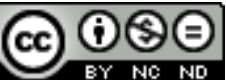

Creative Commons Attribution-NonCommercial-NoDerivatives 4.0 International License 